\title{
Effects of Moringa oleifera Leaves Powder in Fish Feed Toward Growth Rate and Health of Colossoma macropomum
}

\author{
Safrida Safrida*, Nonong Noviasyah, Khairil Khairil \\ Biology Education Department, Faculty of Teacher Training and Education, Universitas Syiah Kuala, Indonesia \\ *Email: saf_rida@unsyiah.ac.id
}

Submitted: 24 December 2019. Revised: 2 May 2020. Accepted: 1 July 2020

\begin{abstract}
Tambaqui (Colossoma macropomum) is one of freshwater fish that preferred by the community and also in high demand by fish farmers. It has a high selling value and easy to maintain but the growth is slow. One alternative that can be used to improve the fish growth is making rations with the addition of Moringa oleifera leaves. The aim of this study was to determine the effect of Moringa leaves powder on the growth rate and health of $C$. macropomum. This study used an experimental method with Completely Randomized Design (CRD) with 6 treatments and 4 replications. The data were analyzed using ANOVA Test in $\alpha=95 \%$. The results showed that P3 with the addition of $30 \%$ Moringa leaves powder could increase the growth of Colossoma macropomum. An increase in fish body weight, width, and length was $40.1 \%, 21.6 \%$, and $6.4 \%$ respectively. Results of ocular, reflex, and defensive test showed that the fish were in healthy condition compared to their condition before acclimatization. The conclusions of this study is that the addition of Moringa leaves powder in an influential ration can increase the growth and maintain the health of C. macropomum. M. oleifera daily supplement can be used as a substitute for soy flour to promote growth and health of Colossoma macropomum in the seed phase. The addition of M. oleifera can be used as feed supplements to improve the growth and health of Colossoma macropomum.
\end{abstract}

Key words: Colossoma macropomum; Moringa Leaves Powder; Fish Health

How to Cite: Safrida, S., Noviasyah, N., \& Khairil, K. (2020). Effects of Moringa oleifera Leaves Powder in Fish Feed Toward Growth Rate and Health of Colossoma macropomum. Biosaintifika: Journal of Biology \& Biology Education, 12 (2), 186-191

DOI: http://dx.doi.org/10.15294/biosaintifika.v12i2.22655

\section{INTRODUCTION}

Aceh province has great potential in freshwater fish breeding. It was seen by the high demand on freshwater fish, so that the cultivation of freshwater fish would be an alternative for the farmers. One of the freshwater fish that have economic value is Tambaqui (Colossoma macropomum) (Taufiq et al., 2016). Demand and consumption of Colossoma macropomum fish is high in the Banda Aceh community . However, increase in demand could not be fulfilled because of low production with the constraints of slow growth and high feed prices. Fish health is also one factor that must be considered in aquaculture. Healthy fish is a fish that free of disease as well as chemicals that could harm the consumers. Conditions of fish that is susceptible to disease will reduce the productivity, so it takes a feed that not only sufficient for the nutritional needs of fish but also can improve their health.

Moringa oleifera has been used in herbal medicine as antioxidant, antimicrobial, anti-inflammatory, anticancer and antidiabetic. M. oleifera leaves contain protein nutrients (Matic et al., 2018). Feeding animals with $M$. oleifera leaves results in both weight gain and improved nutritional status (Mendieta-Araica et al., 2011). Moringa leaves have large amounts of $\beta$ carotene and vitamin A. Moringa leaves have even 10 times higher vitamin A concentration than carrots, and 12 times higher vitamin $\mathrm{C}$ concentration then orange (Stohs \& Hartman, 2015).

This study aimed to determine the effect of $M$. oleifera leaves powder on growth and health of Tambaqui. The addition of M. oleifera was expected to replace soy flour in Colossoma macropomum feed to improve fish health and feed efficiency.

\section{METHODS}

This study used an experimental research design, which aimed to determine the effect of Moringa leaves powder on growth rate and health of Colossoma macropomum. The study design was a completely randomized design (CRD) with 6 treatments and 4 replications. The treatment consisted of formula $\mathrm{P} 0$ (control), P1, P2, P3, P4 and P5 with the addition of $M$. oleifera by $0 \%, 10 \%, 20 \%, 30 \%, 40 \%$ and $50 \%$ respectively (Table 1). This research was conducted at the Jatu Street Emperom, Jaya Baru sub-district, Banda Aceh District. The study was conducted in MarchMay 2018. 
Table 1. Composition of Feed Test

\begin{tabular}{lcccccc}
\hline \multirow{2}{*}{ Raw material } & \multicolumn{7}{c}{ Treatment $(\%)$} \\
\cline { 2 - 7 } & $\mathrm{P} 0$ & $\mathrm{P} 1$ & $\mathrm{P} 2$ & $\mathrm{P} 3$ & $\mathrm{P} 4$ & $\mathrm{P} 5$ \\
\hline Moringa leaves & 0 & 10 & 20 & 30 & 40 & 50 \\
Soy flour & 0 & 50 & 40 & 30 & 20 & 10 \\
Fine Bran & 0 & 5 & 5 & 5 & 5 & 5 \\
Fish flour & 0 & 10 & 10 & 10 & 10 & 10 \\
Cornstarch & 0 & 5 & 5 & 5 & 5 & 5 \\
Starch & 0 & 5 & 5 & 5 & 5 & 5 \\
Premix (vitamin) & 0 & 5 & 5 & 5 & 5 & 5 \\
Mineral mix & 0 & 5 & 5 & 5 & 5 & 5 \\
Fish oil & 0 & 5 & 5 & 5 & 5 & \\
Pellet & 100 & 0 & 0 & 0 & 0 & 0 \\
Total & 100 & 100 & 100 & 100 & 100 & 100 \\
\hline
\end{tabular}

\section{Moringa Leaves Powder Preparation}

Moringa leaves are picked, separated from the stems and put in a bucket. Then, Moring $a$ leaves were air-dried and crushed using wooden mortar to powder. The powder was then filtered to obtain a more refined powder. Moringa leaves was then weighed according to the treatment doses as follow, $\mathrm{P} 0=0 \% ; \mathrm{P} 1=10 \%$; $\mathrm{P} 2=20 \% ; \mathrm{P} 3=30 \% ; \mathrm{P} 4=40 \% ; \mathrm{P} 5=50 \%$.

\section{Procedure of Maintenance Animal Test}

C. macropomum used was $6.5 \mathrm{~cm}$. Each fish's weight was measured using a weight scale, the width and length of the fish were measured using calipers and the level of health was tested by scoring. Furthermore, the treatment was given to $C$. macropomum for 60 days. During maintenance, Tambaqui were fed in accordance with a predetermined concentration of as much as 3 grams.

\section{Procedures of Tambaqui Health Measurement}

The health level of fish was measured at the time of acclimatization $(0,15,45,60$ days of observation) according to indicators on the Table 2.

Table 2. Indicators of Fish Health Measurement

\begin{tabular}{llc}
\hline Parameter & Indicator & Scoring \\
\hline Ocular Test & Eyes colored clear, slightly protruding outward, eyes looking up and move laterally & 3 \\
& Eyes colored clear, slightly bulging out, eyes looking upward & 2 \\
& Eyes colored clear, and convex & 1 \\
Reflex Test & The fish move in opposite direction when the tank is tapped, body fin and tail expand & 3 \\
& when the head is held in hanging position. & \\
& The fish move in opposite direction when the tank expands when patted and fin fish & 2 \\
& head is held & 1 \\
The fish move in opposite directions when the tank is tapped & 3 \\
Test & Fish flounder with regular heights, fish flounder in certain intervals, and the gill open- & \\
& ing and closing simultaneously. & 2 \\
& Fish flounder with regular heights and fish floundering in a certain time interval & 1 \\
\hline
\end{tabular}

(Source: Kurniaji, 2014)

\section{Statistical analysis}

Statistical analysis was done at a significance level $(\alpha)$ of 0.05 . Measurement scores were subjected to analysis of variance (ANOVA). When significant differences in ANOVA were detected, the mean values were compared using the LSD and HSD test.

Data obtained by observing the health of Tambaqui fish were analyzed by descriptive quantitative and tabulated into a table of ocular, reflex, and defensive test scoring ( 1 = very unhealthy, 2 $=$ unhealthy, and $3=$ healthy).

\section{RESULTS AND DISCUSSION}

The results showed that the growth of C. macropomum had an average value of length, width in each treatment (Figure 1,2,3). P3 treatment showed that growth fish was the best compared to other treatments. Statistical analysis on body length of Colossoma macropomum after being treated for 60 days showed significantly different from the Fcount value of 288.15> Ftable 2,773. In order to determine the differences among the treatments, the data was tested further with advanced test BNT 0,05 (Table 4). 


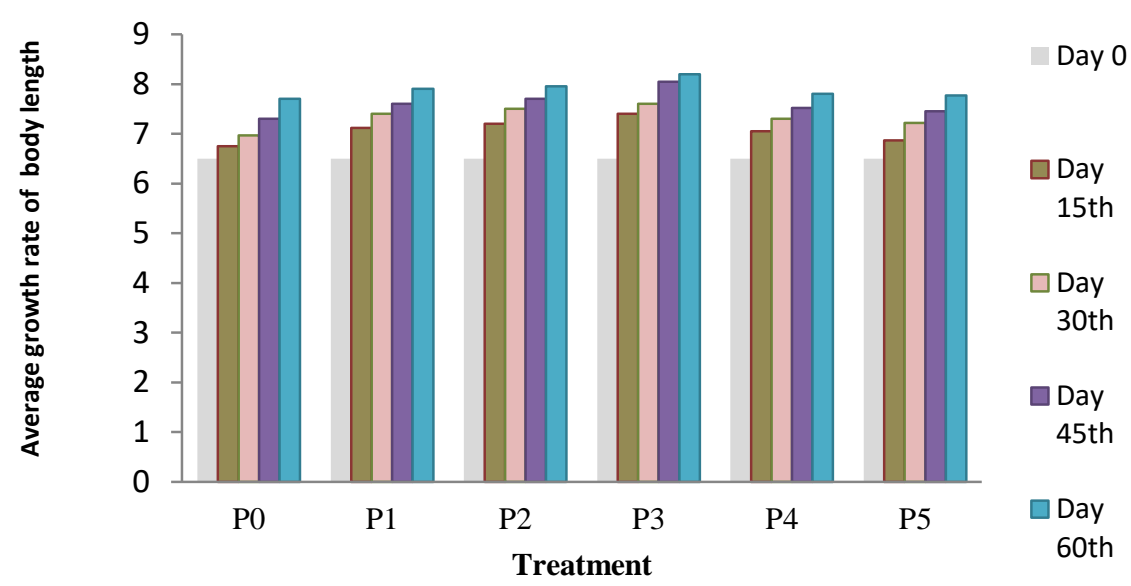

Figure 1. The average growth rate of C. macropomum body length

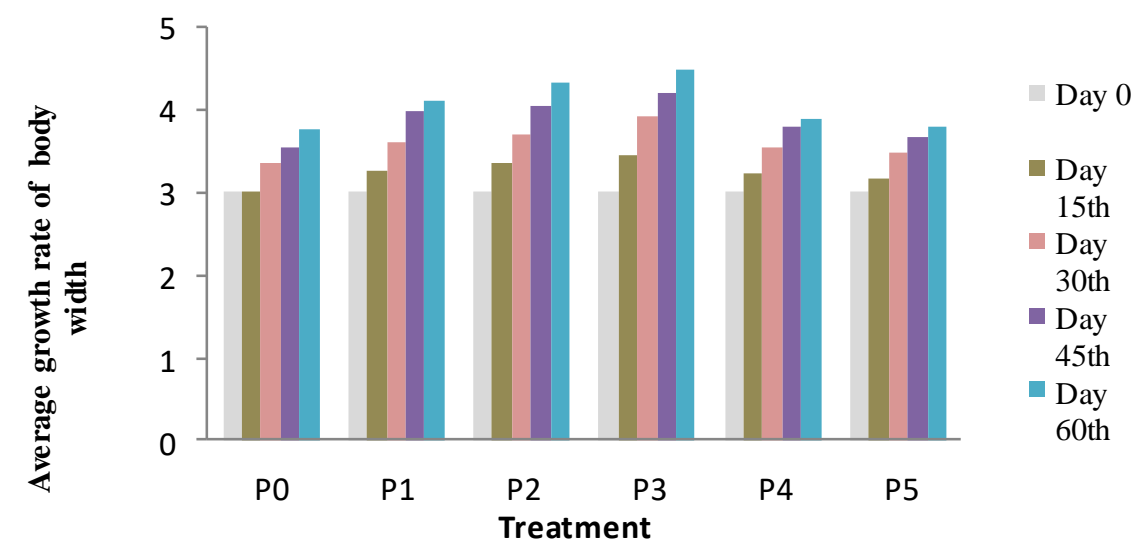

Figure 2. The average growth rate of C. macropomum body width

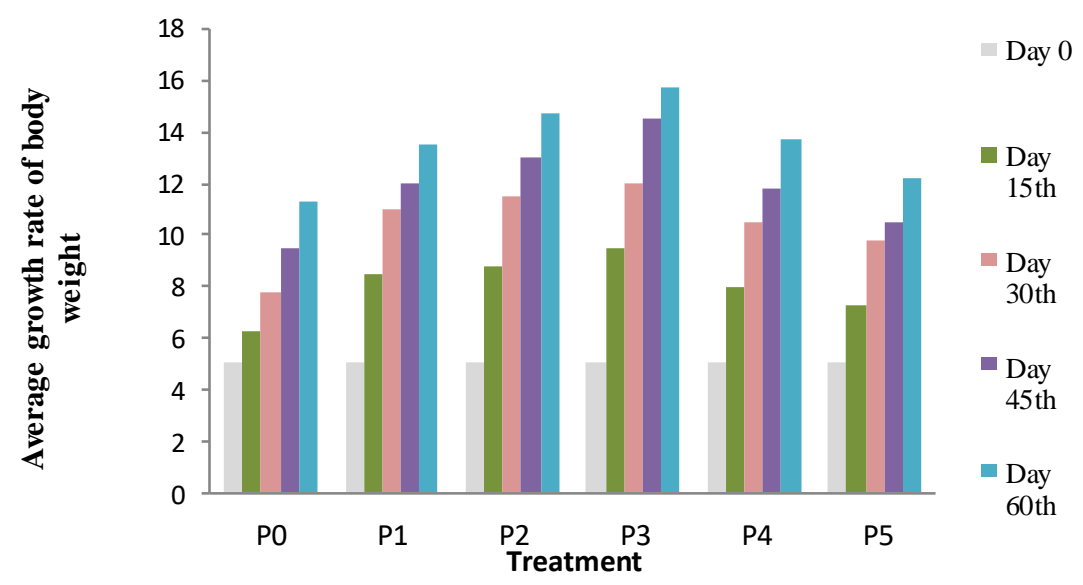

Figure 3. Average growth rate of C. macropomum body weight

Table 4. Average Length, Width, and Weight of Colossoma macropomum

\begin{tabular}{llll}
\hline Treatment & Average lenght & Average Width & Average Weight \\
\hline P0 & $7.04 \mathrm{a}$ & $3.33 \mathrm{a}$ & $7.95 \mathrm{a}$ \\
P1 & $7.30 \mathrm{~d}$ & $3.59 \mathrm{~d}$ & $10.00 \mathrm{c}$ \\
P2 & $7.37 \mathrm{e}$ & $3.69 \mathrm{e}$ & $10.60 \mathrm{~d}$ \\
P3 & $7.55 \mathrm{f}$ & $3.81 \mathrm{f}$ & $11.35 \mathrm{e}$ \\
P4 & $7.23 \mathrm{c}$ & $3.50 \mathrm{c}$ & $9.80 \mathrm{c}$ \\
P5 & $7.16 \mathrm{~b}$ & $3.43 \mathrm{~b}$ & $8.95 \mathrm{~b}$ \\
\hline
\end{tabular}


Statistical test results have shown that the addition of Moringa leaf powder in a certain ratio significantly influences the growth of C. macropomum. The highest growth rate was obtained from P3 with the concentration of Moringa leaves powder as much as $30 \%$. A balance feed composition contained in P3 is more suitable for the growth of $C$. macropomum. This is in accordance with Dienye et al., (2014) that stated that the addition of Moringa leaves powder with a concentration of $30 \%$ for Tilapia feed has been recommended as an alternative to artificial feed that can support the growth well. According to Aminah et al. (2015), the protein content of Moringa leaves have increased from $22.7 \%$ to $28.44 \%$ after being processed to powder. Fish seed needs of protein is also relatively low, $25 \%$ protein content in the diet has been able to support its growth (Mahyuddin, 2011).

Calcium also has an important role in the growth of living things. The amount of calcium in fresh and dried Moringa leaves are 350-550 mg and 1600-2200 $\mathrm{mg}$ respectively. Moringa leaf flour can be used for better fish seed growth. According to Asfiya (2017), the growth rate of fish is closely related to body weight and it is closely related to the protein content as well. Protein in Moringa leaves as powder is higher than that in the fresh one. This is in line with the increase in the carbohydrate content of Moringa leaves if used as powder. It is inversely proportional to the content of the water that decreases. Aminah et al. (2015) stated that the water content of fresh and dried Moringa leaves are $94.01 \%$ and $4.09 \%$ respectively. Therefore, the addition of Moringa leaves in the form of powder will improve feed quality.

One of the essential nutrients needed by fish is protein. This is because protein is a substance that is needed for their growth. The utilization of protein for fish growth is influenced by several factors, including the size and age of the fish, the quality of protein and energy content of the feed, the water temperature, and the frequency of feeding. Protein is one of the nutrients that fish need for growth (Dani et al., 2005). The protein obtained from feed added with Moringa leaves will help to accelerate the growth of fish by increasing the volume and mass of cells, causing the fish to grow well. According to Bello et al. (2013), Moringa leaf flour supplementation as a substitute for fish powder with a concentration of $10 \%$ can accelerate the growth of fish.

Feeds that have been developed in fish growth include the combination of Hermetia illucens larvae powder and Manihot esculenta leaf powder for fish growth (Aini et al., 2018). Spirulina platensis can be used as a food supplement in fish maintenance as a daily supplement (Simanjuntak et al., 2018). Fish feed combinations are also related to fish conservation efforts (Setiati et al., 2018)

Table 5. Results of Health Monitoring of Colossoma macropomum for 60 Days

\begin{tabular}{|c|c|c|c|c|c|c|c|c|c|c|c|c|c|c|c|c|c|c|}
\hline \multirow[b]{3}{*}{ Treatment } & \multicolumn{18}{|c|}{ Day } \\
\hline & \multicolumn{3}{|c|}{$\begin{array}{l}\text { Before Accli- } \\
\text { matization }\end{array}$} & \multicolumn{3}{|l|}{0} & \multicolumn{3}{|l|}{15} & \multicolumn{3}{|l|}{30} & \multicolumn{3}{|l|}{45} & \multicolumn{3}{|l|}{60} \\
\hline & 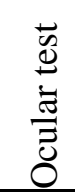 & 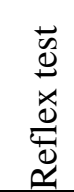 & 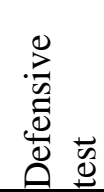 & 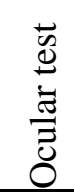 & 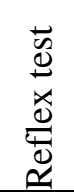 & 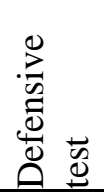 & 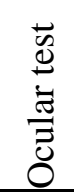 & 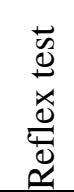 & 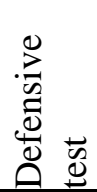 & 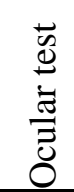 & 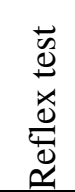 & 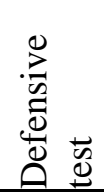 & 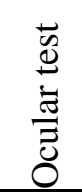 & 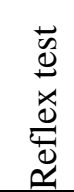 & 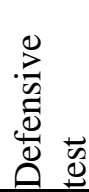 & 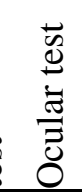 & 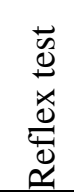 & 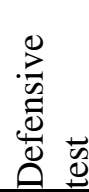 \\
\hline P0 & 3 & 3 & 3 & 3 & 3 & 3 & 3 & 3 & 3 & 3 & 3 & 3 & 3 & 3 & 3 & 3 & 3 & 3 \\
\hline $\mathrm{P} 1$ & 2 & 2 & 2 & 3 & 3 & 3 & 3 & 3 & 3 & 3 & 3 & 3 & 3 & 3 & 3 & 3 & 3 & 3 \\
\hline $\mathrm{P} 2$ & 3 & 3 & 3 & 3 & 3 & 3 & 3 & 3 & 3 & 3 & 3 & 3 & 3 & 3 & 3 & 3 & 3 & 3 \\
\hline P3 & 2 & 2 & 2 & 3 & 3 & 3 & 3 & 3 & 3 & 3 & 3 & 3 & 3 & 3 & 3 & 3 & 3 & 3 \\
\hline P4 & 3 & 3 & 3 & 3 & 3 & 3 & 3 & 3 & 3 & 3 & 3 & 3 & 3 & 3 & 3 & 3 & 3 & 3 \\
\hline P5 & 2 & 2 & 2 & 3 & 3 & 3 & 3 & 3 & 3 & 3 & 3 & 3 & 3 & 3 & 3 & 3 & 3 & 3 \\
\hline
\end{tabular}

Information: 1 = Very unhealthy; $2=$ Unhealthy; 3 = Healthy 


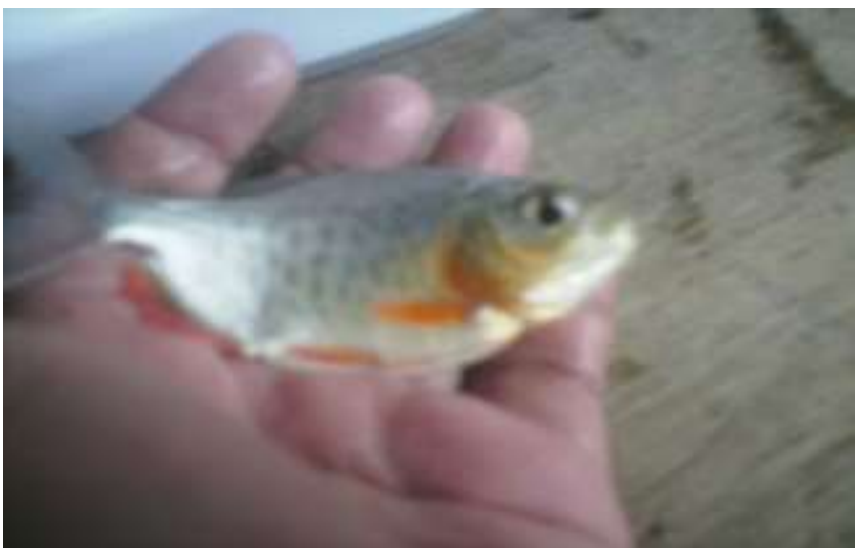

Figure 4. Ocular test photo after giving treatment in C. macropomum

Based on the scoring through the ocular, reflex, and defensive test, fish were in healthy state after the addition of Moringa leaves powder in the ration during 60 days of maintenance. The results in Table 5 shown that fish that have been given Moringa leaves powder are still remain healthy, so this kind of diet can be used as an alternative feed for Colossoma macropomum.

The nutritional content of Moringa leaves are used in the form of powder can increase the amount of protein content. According to Aminah et al. (2014), amino acids contained in the dried Moringa leaves is higher than in fresh leaves. Moringa leaves contain compounds that can enhance the immune system. Furthermore, it has been proposed that Moringa oleifera leaves extracts contain a large number of phenolic compounds such as epicatechin, flavonoids, cinnamic acid, protocatechuic acid, vanillin, caffeic acid, ferulic acid, p-coumaric acid, kaempferol, gallic acid, catechin, and quercetin (Govardhan et al., 2013). The secondary metabolites identified from Moringa extract have been shown to protect against chronic diseases through the action of various biological profiles including antioxidant, analgesic, anti-diabetic, diuretic, antibacterial, anti-tuberculosis, anti-cancer, antispasmodic, antihypertensive, antimicrobial, antimalarial, cholesterol lowering and antioxidant activities (Saini et al., 2016). According Hurriyani (2013), the bioactive compounds such as flavonoids are also known to able to improve the work of the immune system as leukocytes produced more quickly and lymphatic system is activated. An increase in the number of leukocytes shows cellular immune response in addressing the influx of foreign substances in the body such as a bacterial infection. The leukocytes function as the immune system of fish react to interference from outside including pathogen infection. Flavonoids are thought to play an important role in increasing the resistance of fish to pathogens. This is related to the ability of antioxidants to boost the immune system performance. Antioxidants of flavo- noids are known to increase the phagocytic activity which is a function of the non-specific cellular immune response.

The mechanism of antioxidant flavonoids, polyphenols and carotenoids in enhancing phagocytic activity (Iwama \& Nakanishi, 1996). Flavonoids, major phenolic act as an antioxidant because they have a hydroxyl group that can donate a hydrogen atom to the free radical compounds and stabilizing the reactive oxygen species (ROS) and has a hydroxy ketone which can act as a catalyst in lipid peroxides (Rezaeizadeh et al., 2011).

Amino acids are also taking an important role on the immune system. If fish amino acid deficiency will result in amino acids cannot be used, while if advantages mino acids so that fish growth is compromised, it can be related to the physiological functions of the body of the fish (Asminatun, 2010).

This research can contribute to fish farmers to be able to provide $M$. oleifera supplements as a substitute for soybean flour. $M$. oleifera powder supplements can also be used as a daily supplement to improve the growth and health of Colossoma macropomum at the time of maintenance until the harvesting age.

\section{CONCLUSION}

Addition of Moringa leaves powder (Moringa oleifera) in fish feed could increase the growth rate and maintain the health of Tambaqui (Colossoma macropomum). Suplemention of M. oleifera daily can be used as a substitute for soy flour to promote growth and health of Colossoma macropomum at the seed phase.

\section{REFERENCES}

Aini, N., Nugroho, R.A., \& Hariani, N. (2018). Growth and Survival Evaluation of Oreochromis sp. fed Hermetia illucens Larva and Manihot esculenta leaves Meal. Biosaintifika, 10(3), 565-573.

Aminah, Syarifah., Tezar Ramdhan., Muflihani Yanis. (2015). Kandungan Nutrisi dan Sifat Fungsional Tanaman Kelor (Moringa oleifera). Buletin Pertanian Perkotaan. 5(2).35-44.

Asfiya, M, Safrida S., Abdullah A. (2017). Pengaruh Pemberian Pakan Tambahan dari Keong Mas (Pomacea canaliculata L.) terhadap Pertumbuhan Ikan Gurami (Osphronemus gouramy Lac). Jurnal Ilmiah Mahasiswa Keguruan dan Ilmu Pendidikan Unsyiah. 2 (3). 1-10

Asminatun. (2010). Pembuatan Pakan Ikan Berdasarkan Konsep Protein Ideal yang Ramah Lingkungan. Jurnal UI untuk Bangsa Seri Kesehatan, Sains, dan Teknologi. 1 (1): 70-78. 
Bello, Nuhu Ozovehe, and G. C Nzeh. (2013). Effects of Varying Levels of Moringa oleifera Leaf Meal Diet on Growth Performance, Hematological Indices and Biochemical Enzymes of African Catfish Clarias gariepinus (Burchell 1822). Elixir Aquaculture. 57(A). 14459-14466.

Dani, N. P. Budiharjo A. Listyawati S. (2005). Komposisi Pakan Buatan Untuk Meningkatkan Pertumbuhan dan Kandungan Protein Ikan Tawes (Puntius javanicus). BioSMART. 7(2). 83-90.

Dienye, H. E and O. K.Olumuji. (2014). Growth Performance and Haematological Responses of African Mud Catfish Clarias gariepinus Fed Dietary Levels of Moringa oleifera Leaf Meal. Net Journal of Agricultural Science. 2(2). 79-88.

Govardhan SRS, Pradeep N, Radha C. (2013). Phenolic composition, antioxidant and antimicrobial activities of free and bound phenolic extracts of Moringa oleifera seed flour. Journal of Functional Foods 5(4):1883-1891

Hurriyani, Yeni. (2013). Uji Potensi Tanaman PaciPaci (Leucas lavandulaefolia) sebagai Bahan Alternatif untuk Pengobatan Ikan. Vokasi. IX(2): $110-115$.

Iwama, G., and Nakanishi, T. (1996). The Fish Immune System. [Book]. London: Academic Press

Kurniaji, A. (2014). Patologi Ikan. Laporan Praktikum Patologi Ikan. Bogor: Institut Pertanian Bogor.

Mahyuddin. (2011). Usaha Pembenihan Ikan Bawal Di Berbagai Wadah. Jakarta: Penebar Swadaya.

Matic, I, Arianna Guidi., Maurice Kenzo., Maurizio Mattei., Andrea Galgani. (2018). Investigation of medical plants traditionally used as dietary supplements: a review on Moringa oleifera. Journal of Public Health in Africa. 9(841): 191-199.
Mendieta-Araica B, Spörndly E, Reyes-Sánchez N, Spörndly R. (2011). Feeding Moringa oleifera fresh or ensiled to dairy cows: effects on milk yield and milk flavor. Trop Anim Health Prod. 43(10): 39-47.

Rezaeizadeh, A., Zuki, A.B.Z., M. Abdollahi., Goh, Y.M., Noordin, M.M., Hamid, M., dan Azmi, T.I. (2011). Determination of Antioxidant Activity in Methanolic and Chloroformic Extract of Momordica Charantina. African Journal of Biotechnology. 10 (24). 4932-4940.

Saini RK, Sivanesan I, Keum YS. (2016). Phytochemicals of Moringa oleifera: a review of their nutritional, therapeutic and industrial significance. Biotech 6:20

Setiati N, Peniati E, Partaya. (2018). Diversity and Conservation Knowledge of Chondrichthyans in Northern Coastal Areas of Central Java. Biosaintifika 10 (2) (2018) 471-476.

Simanjuntak SBI, Wibowo ES, Indarmawan. (2016). Stimulation of Deprivation Cycles with Spirulina platensis Feed Supplementation on Osphronemus gouramy Physiological Responses. Biosaintifika 8 (3), 377-384

Stohs SJ, Hartman MJ. (2015). Review of the Safety and Efficacy of Moringa oleifera. Phytother Res 29: 796-804

Taufiq, Firdus, dan Iko Imelda Arisa. (2016). Pertumbuhan Benih Ikan Bawal Air Tawar (Colossoma macropomum) pada Pemberian Pakan Alami yang Berbeda. Jurnal Ilmiah Mahasiswa Kelautan dan Perikanan Unsyiah. 1 (3): 355-365.

Winarsi, H. (2007). Antioksidan Alami dan Radikal Bebas: Potensi dan Aplikasinya dalam Kesehatan. Yogyakarta. Kanisius. 